\title{
KESENJANGAN PENGALIRAN ARUS INFORMASI DI DUNIA ISLAM
}

\author{
Putri Rahmadhani Lubis, Toguan Rambe \\ Universitas Islam Negeri Sumatera Utara Medan, Universitas Islam Negeri Sumatera \\ Utara Medan
}

\begin{abstract}
ABSTRAK
Komunikasi global merupakan salah satu kekuatan yang sedang berkembang dewasa ini. Kehadirannya telah mempengaruhi berbagai aspek kehidupan seperti politik, ekonomi, budaya, militer, dan sebagainya. Kebijakan dan peraturan yang berjalan di dunia Internasional tentunya tidak terlepas dari adanya peran komunikasi secara global. Persoalan yang menarik untuk dibahas bagaimana dunia Islam dalam menghadapi persoalan komunikasi global tersebut. Peran apa yang dimainkan oleh Islam dalam percaturan komunikasi global, serta upaya apa yang mesti dilakukan agar Islam dapat berperan secara signifikan dalam komunikasi global. Frekuensi berita tentang umat Islam yang diliput oleh kantor berita internasional masih dinilai sangat kecil dan belum balance (seimbang) dan masih menggambarkan ketidakadilan sehingga merugikan umat Islam. Negara Barat memiliki dominasi yang cukup kuat dalam pengaliran arus informasi, khususnya Amerika Serikat. Kategori berita yang paling banyak muncul ialah kematian, tindak kekerasan, pemberontakan, peperangan, dan terorisme. Sehingga orientasi berita umumnya adalah bersifat negatif.
\end{abstract}

Kata kunci : Kesenjangan, Komunikasi Global, Dunia Islam

\begin{abstract}
ABSRACT
Global communication is one of the forces that is developing today. Its presence has influenced various aspects of life such as politics, economy, culture, military, and so on. Policies and regulations that run in the international world certainly cannot be separated from the role of communication globally. An interesting issue to discuss is how the Muslim world faces global communication problems. What role does Islam play in the arena of global communication, and what efforts must be made so that Islam can play a significant role in global communication. The frequency of news about Muslims covered by international news agencies is still considered to be very small and not yet balanced and still illustrates injustice to the detriment of Muslims. Western countries have a strong enough dominance in the flow of information flow, especially the United States. The most emerging categories of news are death, violence, rebellion, warfare and terrorism. So that news orientation is generally negative.
\end{abstract}

Keywords: Gaps, Global Communication, Islamic World 


\section{PENDAHULUAN}

Komunikasi Internasional (International Communication) adalah komunikasi yang dilakukan oleh komunikator yang mewakili suatu negara untuk menyampaikan pesan-pesan yang berkaitan dengan kepentingan negaranya kepada komunikan yang mewakili negara lain. Komunikasi internasional merupakan instrument yang sangat penting dalam dinamika hubungan internasional. Negara yang memiliki kepentingan di negara lain akan mengkomunikasikan hal- hal yang berkaitan dengan kepentingan tersebut, baik itu berupa kerjasama maupun konflik. Pada saat yang bersamaan negara yang dituju tersebut memberikan reaksi, saat itulah komunikasi internasional berjalan.

Komunikasi global merupakan salah satu kekuatan yang sedang berkembang dewasa ini. Kehadirannya telah mempengaruhi berbagai aspek kehidupan seperti politik, ekonomi, budaya, militer, dan sebagainya. Kebijakan-kebijakan dan peraturan-peraturan yang berjalan di dunia internasional tentu-nya tidak terlepas dari adanya peran komunikasi secara global. Persoalan yang menarik untuk dibahas bagaimana dunia Islam dalam menghadapi persoalan komunikasi global tersebut. Peran apa yang dimainkan oleh Islam dalam percaturan komunikasi global, serta upaya apa yang mesti dilakukan agar Islam dapat berperan secara signifikan dalam komunikasi global.

Belakangan ini, telah diketahui bahwa pengaliran berita Internasional sebahagian besar di kuasai oleh kantor berita Negara-negara barat terutama Amerika, Inggris dan Perancis. Empat kantor berita yang terbesar, yaiti Associated Press ( AP), dari dari Serikat, Reuter dari Inggris, Agence frence Presse (AFP) dari Perancis, tetap menjadi sumber utama berita Internasional terutama bagi Negara-negara Timur. ${ }^{1}$

Dalam tulisan ini, penulis mencoba untuk menganalisis sejauh mana peranan aliran inforrmasi di negara-negara Islam oleh pemberitaan kantor-kantor berita dunia. Serta sedikit banyaknya akan dibahas mengenai kesenjangan informasi yang di beritakan baik dari segi frekuensi maupun isi, faktor-faktor penyebabnya, dan akibat yang muncul terutama bagi dunia Islam.

\footnotetext{
${ }^{1}$ Syukur Kholil, Komunikasi Islami ( Bandung: Citapustaka,2007), h 82
} 


\section{SEJARAH PERKEMBANGAN INFORMASI GLOBAL DI DUNIA ISLAM}

Islam sebagai agama rahmatan lil 'alamin memiliki nilai-nilai dan tradisi berkomunikasi. Dalam perjalanan sejarahnya, nilai-nilai dan tradisi berkomunikasi yang telah dibangun pondasi-pondasinya pada jaman Rasulullah, mengalami pasangsurut sesuai dengan dinamika yang berkembang dalam perjalanan sejarah umat Islam. Secara teologis, Islam tidak menjadi hambatan untuk menjadikan umatnya maju dan berkembang. Bahkan, Islam sangat mendorong umatnya untuk menjadi umat yang terbaik di muka bumi ini (Q.S. Fathir: 24).

\section{"Sesungguhnya kami mengutus kamu dengan membawa kebenaran sebagai pembawa berita gembira dan sebagai pemberi peringatan dan tidak ada suatu umat pun melainkan telah ada padanya seorang pemberi peringatan “ 2}

Hubungan dengan dunia luar dalam konteks komunikasi terjadi pertama kali dengan diperkenalkannya mesin cetak oleh penguasa Mongol pada awal abad ke-13 di wilayah Iran. Umat Islam di wilayah ini diperkenalkan mesin percetakan model Cina yang dipergunakan untuk mencetak uang kertas. ${ }^{3}$ Dan pada abad ke-15 Turki mengenal mesin cetak yang ditemukan oleh Gutenberg yang banyak dimanfaatkan oleh Barat untuk mengembangkan ilmu pengetahuan. ${ }^{4}$

Pengenalan dengan mesin cetak ini membawa perubahan dan perkembangan bagi umat Islam terutama dalam pengembangan ilmu pengetahuan. Banyak bukubuku yang berasal dari Barat dan peninggalan-peninggalan umat Islam (termasuk alQur'an) untuk dicetak dan disebarluaskan ke berbagai wilayah Islam. Dari sanalah umat Islam mulai menunjukkan geliatnya untuk bangkit dari tidurnya. Umat Islam mulai menyadari akan ketertinggalannya dengan dunia Barat. Pada awal abad ke-18 umat Islam mulai bangkit untuk mengadakan pembaharuan-pembaharuan, terutama di bidang pemikiran dan politik. Hegemoni Barat dalam Komunikasi Global.

\footnotetext{
${ }^{2}$ Departemen agama RI. Alqur'an dan Terjemahnya. (Bandung : Gema Risalah Pers, 2008)

3 Bernard Lewis, What Went Wrong? The Clash Between Islam and Modernity in the Middle East (New York: Oxford University Press, 2002), hal. 143.

${ }^{4}$ Ibid., hal. 142.
} 
Sejak jatuhnya Islam dan terjadinya revolusi industri di negara-negara Barat, maka Barat mulai tampil sebagai pemain utama dalam penguasaan di bidang komunikasi. Ditemukan mesin cetak oleh Gutenberg membawa dampak yang cukup besar bagi perkembangan ilmu pengetahuan dan teknologi. Barat terus melaju dalam pengembangan dan penemuan media komunikasi yang semakin canggih seperti photography, film, telephone, telegraphy, broadcasting, satelite, dan computer, serta internet.

Dengan berkembang pesatnya teknologi komunikasi di Barat, maka Barat terutama Amerika Serikat menguasai informasi dunia. Semua informasi yang berkembang di seluruh dunia bersumber dari media-media yang dikembangkan oleh Barat. Barat telah melakukan hegemoni dengan kekuatan komunikasi yang dimilikinya.

Sebagaimana pernyataan Huntington yang juga diakui oleh Akbar S. Ahmed bahwa pada abad ke-20 dan ke-21, Amerika dan negara-negara Eropa Barat nampak mendominasi dunia, terutama melalui media komuni-kasi. 21 Kantor berita yang dimiliki negara-negara maju yang berpusat di New York, London dan Paris, seperti AP, UPI, AFP dan Reuter, tidak saja berperan dalam pembuat berita, tetapi juga menjadi penentu berita-berita apa yang layak disalurkan ke negara-negara. ${ }^{5}$

Usai perang dunia ke dua, perkembangan kapitalisme di Amerika Serikat mempengaruhi kebebasan arus informasi di negara tersebut, termasuk dalam hubungan internasional. Bahkan Amerika Serikat melegitimasi suatu ekspresi seiring dengan kebebasan hubungan internasionalnya, meliputi kebebasan kapital, sumber bahan baku dan arus informasi. John Knight (1946), President of the American Society of Newspaper Editor menyatakan bahwa kebebasan arus informasi tidak hanya bertolak belakang dengan pemahaman kaum fasis namun juga berkaitan dengan harapan perdamaian.

Selanjutnya setelah perang dunia kedua William Benton, asisten sekretaris negara Amerika mengungkapkan kebijakan luar negeri mengenai arus informasi di Amerika Serikat. Diantaranya Amerika serikat akan melakukan upaya apa saja dengan kekuasaan politik dan jalur diplomasi yang dimilikinya dalam menghadapi batasan

\footnotetext{
${ }^{5}$ Samuel P. Huntington. Benturan Antarperadaban dan Masa Depan Politik Dunia. Yogyakarta: Penerbit Qalam, 2001. h 78
} 
artifisial yang diciptakan pihak tertentu dalam menghadapi ekspansi kantor berita, majalah, film, dan komunikasi media Amerika Serikat lainnya ke seluruh dunia. Terutama kebebasan pers dan pertukaran informasi secara umum. Begitu pula bagi dunia Islam.

\section{KESENJANGAN ARUS INFORMASI DARI SEGI FREKUENSI DAN ISI}

Persoalan mendasar terletak pada posisi Islam dalam komunikasi global di mana hegemoni Barat begitu kokoh dan menjadi pemain utamanya. Dihadapkan pada persoalan tersebut, ternyata Islam tidak memiliki posisi yang signifikan. Sama halnya dengan negara-negara dunia lain pada umumnya. Mereka hanya sebagai negara yang banyak bergantung kepada informasi yang diberikan oleh Barat, khususnya Amerika Serikat. Dalam hal media komunikasi pun, umumnya negara-negara dunia, termasuk Islam hanya sebagai konsumen yang pemanfaatannya belum maksimal dirasakan oleh seluruh warga negaranya. Apalagi menjadi produsen dalam mencipta-kan media komunikasi, rasanya terlalu jauh untuk diharapkan.

Berita-berita yang dilansir oleh media Barat tentang Islam umumnya bersifat pejoratif dan steoretipe. Menurut Edward W. Said, banyak pemberitaan tentang Islam yang disajikan secara superfisial oleh media massa Barat. Hal itu terjadi bisa karena ketidaktahuan atau kesengajaan. Yang sering terjadi bahwa wartawan yang dikirim bukan hanya tidak mengetahui bahasa atau budaya lokal, tetapi juga asing terhadap wilayah di mana ia ditugaskan. Dalam situasi demikian, apa yang diberitakan adalah apa yang diketahui secara superfisial atau sesuatu yang ada di tangan. Dalam hal demikian kualitas dan akurasi berita tidak menjadi persoalan lagi. Sekalipun demikian, berita yang superfisial itu pun tidak akan ditentang konsumen berita di Barat. $^{6}$

Dalam penelitiannya, Prof. Dr. Syukur Kholil, M.A menyatakan bahwa sifat berita pada umumnya berita-berita tentang ummat Islam yang bersumber dari kantor berita internasional yang disiarkan pada surat kabar terbitan Medan tergolong kepada berita biasa $(81,8 \%)$. Tetapi ada juga yang dijadikan sebagai berita headline pada halaman tertentu $(18,2 \%)$. Skor penonjolan tentang umat Islam pada surat kabar yang dikaji

\footnotetext{
${ }^{6}$ Edward W. Said. Covering Islam, Terj. Oleh Apri Danarto (Yogyakarta: Penerbit Jendela, 2002), hal
} 
pada umumnya adalah sangat tidak menonjol(42,9\%), tidak menonjol (27,3\%), sedang (13,0\%), menonjol (16,9\%), dan tidak ada satu juudul berita ppun yang disiarkan sangat menonjol.

Negara yang dijadikan sebagai asal berita yang paling banyak adalah Irak (16,9\%), kemudian Pakistan dan USA masing-masing 9,1\%. Kategori berita tentang umat Islam yang paling banyak ialah kematian (19,5\%), pemberontakan $(15,8 \%)$, dan peperangan $(10,4 \%)$. Kebanyakan berita tentang umat *Islam yang diliput oleh kantor berita internasional yang disisrkan pada surrat kabar terbitan Medan adalah berorientasi negatif ( $74,0 \%)$, naamun ada juga yang berorientasi positif $(18,2 \%)$ sisanya $(7,8 \%)$ berorientasi netral. Dengan demikian hasil liputan tentang umat Islam yang disiarkan pada surat kabar terbitan Medan masih menggambarkan ketidakseimbangan (imbalance) dan ketidak adilan, sehingga dapat merugikan umat Islam. $^{7}$

\section{FAKTOR-FAKTOR PENYEBAB KESENJANGAN ARUS INFORMASI}

Penyebab terjadinya ketidakseeimbangan pengaliran arus informasi tentang umat Islam disebabkan oleh beberapa faktor yaitu akibat perbedaan kemampuan ekonomi yang menyolok. Amerika dan Eropa dengan laju pertumbuhan ekonomi yang baik, akan menjadi raksasa pula dalam bidang teknologi. Perbedaan kemampuan di bidang sains dan teknologi juga mempengaruhi, dimana sains dan teknologi modern dikuasai oleh negara-negara Eropa dan Amerika, sedangkan negara-negara Islam sebahagian besar merupakan konsumen atau pengguna hasil teknologi negara-negara Eropa dan Amerika. Sehingga timbul ketergantungan negara-negara islam kepada negara-negara maju.

Begitu pula dengan tidak adanya kesamaan hak antara negara-negara maju dengan negara-negara berkembang khususnya dibidang informasi dan komunikasi. Negaranegara maju menguasai media massa negara islam. Akibatnya negara-negara islam berperan sebagai pengguna informasi yang dijual sebagai benda berharga oleh negaranegara maju. Serta kurangnya huubungan yang saling menguntungkan diantara

\footnotetext{
7 Syukur kholil. Komunikasi Islami....h 94-101
} 
negara-negara Eropa/Amerika dengan negara-negara Islam dalam bidang informasi dan koomunikasi.. ${ }^{8}$

\section{AKIBAT YANG TIMBUL BAGI DUNIA ISLAM}

Implikasi yang timbul dari posisi Islam seperti itu, dalam komunikasi global tentunya Islam belum memiliki kekuatan untuk berperan secara signifikan. Kehadiran Islam dalam komunikasi global baru sebatas wacana yang memiliki potensi besar untuk bangkit. Media-media yang banyak dimanfaatkan oleh Iran dalam membangun revolusinya seperti yang diungkapkan oleh Majid Tehranian dalam bukunya Global Communication and World Politics belum memberikan peran dalam percaturan global. Begitu juga, kantor-kantor berita yang ada di negara-negara Arab belum mampu menjadi pemasok berita utama di kalangan masyarakat muslim maupun masyarakat dunia. ${ }^{9}$

Sifat konsumerisme pada negara-negara Islam menimbulkan ketergantungan negara-negara islam kepada negara-negara maju. Negara-negara maju yang menguasai media massa negara islam mengakibatkan negara-negara islam berperan sebagai pengguna informasi yang dijual sebagai beenda berharga oleh negara-negara maju. Agar lebih meningkatkan perannya dalam komunikasi global, maka umat Islam sudah seharusnya melakukan upaya-upaya sistematis untuk mengejar ketertinggalannya.

frekuensi berita tentang umat Islam yang diliput oleh kantor berita internasional masih dinilai sangat kecil dan belum balance (seimbang) dan masih menggambarkan ketidakadilan sehingga merugikan umat Islam. Hal ini belum sejalan dan efektif dengan teori komunikasi massa seperti teori agenda setting dan teori penyuburan. Sebab, siaran agama belum dianggap penting oleh pihak media, melainkan merupakan agenda pelengkap untuk memenuhi kebutuhan audien. Atau berdasarkan teori penyuburan, nilai-nilai Islam akan dapat diyakini dan di amalkan oleh umat manusia apabila penyampaianya dilakukan secara terus menerus sehingga nilai-nilai Islam yang di anut akan semakin subur baik pada tatanan pengetahuan maupun pada tatanan pengamalannya.

\footnotetext{
8 Syukur Kholil. Komunikasi islami.... h 108

9 http://panduummat.wordpress.com/2011/03/17/islam-dan-komunikasi-global/
} 


\section{KESIMPULAN DAN SARAN}

Berdasarkan pembahasan diatas, maka dapat disimpulkan bahwa frekuensi berita tentang umat Islam yang diliput oleh kantor berita internasional masih dinilai sangat kecil dan belum balance (seimbang) dan masih menggambarkan ketidakadilan sehingga merugikan umat Islam. Negara Barat memiliki dominasi yang cukup kuat dalam pengaliran arus informasi, khususnya Amerika Serikat. Kategori berita yang paling banyak muncul ialah kematian, tindak kekerasan, pemberontakan, peperangan, dan terorisme. Sehingga orientasi berita umumnya adalah bersifat negatif.

Upaya-upaya yang harus dilakukan adalah: Pertama, menjadikan ajaran Islam sebagai sumber vitalitas peradaban; Kedua, membangun kerja sama yang harmonis antara Islam dengan Barat, terutama medianya; Ketiga, meningkatkan kemampuan umat Islam dalam penguasaan ilmu dan teknologi, khususnya komunikasi serta membangun kantor-kantor berita dunia; Keempat, institusi-institusi Islam dapat memainkan perannya dalam percaturan global; Kelima, kerjasama antarnegara Islam perlu ditingkatkan. Agar lebih meningkatkan perannya dalam komunikasi global, maka umat Islam sudah seharusnya melakukan upaya-upaya sistematis untuk mengejar ketertinggalannya. 


\section{DAFTAR PUSTAKA}

Departemen agama RI. Alqur'an dan Terjemahnya. Bandung : Gema Risalah Pers, 2008

Huntington, Samuel P. Benturan Antarperadaban dan Masa Depan Politik Dunia. Yogyakarta: Penerbit Qalam, 2001.

Kholil,Syukur. Komunikasi Islami . Bandung: Citapustaka, 2007

Lewis,Bernard. What Went Wrong? The Clash Between Islam and Modernity in the Middle East .New York: Oxford University Press, 2002.

Said, Edward W. Covering Islam, Terj. Oleh Apri Danarto (Yogyakarta: Penerbit Jendela, 2002),

http://panduummat.wordpress.com/2011/03/17/islam-dan-komunikasi-global/ 